\title{
New insights on the morphology of a digenean parasite (Digenea: Brachylaimidae, Brachylaima mazzantii (Travassos, 1927)) using confocal laser scanning microscopy
}

\author{
Juçara de Souza MARQUES \\ Bárbara Marum ROCHA \\ Malacological Museum Professor Maury Pinto de Oliveira, \\ Federal University of Juiz de Fora, Minas Gerais (Brazil) \\ Pedro Paulo de Abreu MANSO \\ Departament of Pathology, Oswaldo Cruz Institute, \\ Rio de Janeiro (Brazil) \\ Sthefane D'ÁVILA \\ Malacological Museum Professor Maury Pinto de Oliveira and Departament of Zoology, \\ Federal University of Juiz de Fora, Minas Gerais (Brazil) \\ sthefanedavila@hotmail.com
}

Published on 29 December 2017 urn:Isid:zoobank.org:pub:0F5D59AF-1AF2-4BD3-8C26-1198D5766D9E

Marques J. S., Rocha B. M., Manso P. P. A. \& D’Ávila S. 2017. - New insights on the morphology of a digenean parasite (Digenea: Brachylaimidae, Brachylaima mazzantii (Travassos, 1927)) using confocal laser scanning microscopy. Zoosystema 39 (4): 449-462. https://doi.org/10.5252/z2017n4a1

KEY WORDS

Cirrus pouch, seminal reservoir, esophagus

tegument ornamentation.

\section{ABSTRACT}

Brachylaima mazzantii (Travassos, 1927) is known only from its original description. Until now, no attempt has been made to address the morphology of this species by means of modern microscopy techniques. In the present study, the information generated on the anatomy of $B$. mazzantii allowed the re-examination of the morphology of this species. The most significant new data is related to the terminal genitalia. The detailed analysis of the reproductive system of this species evidenced the presence of a seminal vesicle external to the cirrus pouch which contains a short unarmed cirrus, and also the presence of a well developed metraterm and gland cells in the genital atrium. The results also revealed some traits concerning other systems, previously unnoticed, including the shape and relative position of the excretory vesicle and the tegument ornamentation. The main advantage of using confocal microscopy to study the morphology of digeneans is the fact that with only one technique it is possible to examine the gross anatomy, cell morphology and surface topography. Confocal tomographies show much more detail than light microscopy images, and allow getting information on cell morphology, usually achieved only by histological techniques, along with some information on tegument ornamentation, usually obtained through scanning electron microscopy. The accumulation of information on the morphology of different digenean species through confocal microscopy will allow future comparative studies, which may ultimately contribute to the better resolution of the systematics of this group. 


\author{
MOTS CLÉS \\ Poche du cirre, \\ réservoir séminal, \\ œsophage, \\ ornamentation du tégument.
}

\begin{abstract}
RÉSUMÉ
Nouvelles observations sur la morphologie d'un parasite digénien (Digenea: Brachylaimidae, Brachylaima mazzantii (Travassos, 1927)) par microscopie confocale.

Brachylaima mazzantii (Travassos, 1927) est connu uniquement par sa description originale. Jusqu’à présent, sa morphologie n'a jamais été décrite avec des techniques modernes de microscopie. Dans la présente étude, les résultats obtenus sur l'anatomie de $B$. mazzantii ont permis le re-éxamen de la morphologie de cette espèce. Les résultats les plus significatifs concernent l'appareil génital terminal. L'analyse détaillée du système reproducteur a mis en évidence la présence d'une vésicule séminale externe dont la poche de cirre contient un cirre court et désarmé, ainsi qu'un métraterme bien développé et des cellules glandulaires dans l'atrium génital. Les résultats ont également révélé quelques caractères, jusqu'à présent passés inaperçus, d'autres systèmes, telles que la forme et la position relative de la vésicule excrétrice et l'ornementation du tégument. Le principal avantage de la microscopie confocale pour l'étude de la morphologie des digènes est qu'elle permet d'examiner, à la fois, l'anatomie, la morphologie cellulaire et la topographie de surface. Les tomographies confocales montrent beaucoup plus de détails que les images de microscopie photonique; elles fournissent également des informations sur la morphologie cellulaire, normalement acquises avec des préparations histologiques, et sur l'ornementation du tégument, normalement obtenues par microscopie électronique à balayage. L'accumulation d'information sur la morphologie de différentes espèces de digènes par microscopie confocale permettra dans le futur des études comparatives, qui contribueront à termes à une meilleure résolution de la systématique de ce groupe.
\end{abstract}

\section{INTRODUCTION}

The digenean trematode Brachylaima mazzantii (Travassos, 1927) (Digenea, Brachylaimidae) is an intestinal parasite of domestic and wild columbids. In Brazil this species has been reported parasitizing doves (Columba livia) in Pará, Pernambuco, Minas Gerais, Rio de Janeiro, Mato Grosso, Mato Grosso do Sul, Distrito Federal and São Paulo states (Lent \& Freitas 1937; Costa \& Freitas 1959; Travassos \& Kohn 1966; Freitas et al. 1967; Martins \& Freitas 1975; Costa et al. 1986; Silva et al. 1990). This species was described in the 1920s, by light microscopy, and until now, no new information has been added to the knowledge of its morphology through new techniques.

The improvement of microscopy approaches have made possible great advance in studies of the morphology of digeneans (Robson \& Erasmus 1970; Mair et al. 1998a, b, 2000; AbdulSalam \& Sreelatha 2000, 2004; Stewart et al. 2003; Halton 2004; Neves et al. 2004, 2005). Confocal scanning laser microscopy has become an important tool to clarify the organization of the musculature and innervation, as well as the morphology of the reproductive and alimentary tract of various species (Mair et al. 1998a,b, 2000; Stewart et al. 2003; Neves et al. 2004, 2005; D’Ávila et al. 2010; Machado-Silva et al. 2011).

Some results obtained through confocal microscopy studies have confirmed evolutionary relationships. As an example, several descriptions of the muscle system (Mair et al. 1998b, 2000; Kumar et al. 2003; Šebelova et al. 2004; Terenina et al. 2006; D'Ávila et al. 2010) have strengthened the idea that the organization of the somatic musculature is conserved among the digeneans, as stated by Šebelova et al. (2004). The pattern of vitellogenesis seems to be even more conserved among digeneans, monogeneans, cestodes and free-living neophoran (Swiderski \& Xylander 2000; D’Ávila et al. 2010). In addi- tion, the morphological characterization of the musculature of tubular organs and attachment apparatus has supported some functional interpretations (Mair et al. 1998b, 2000; Šebelova et al. 2004; D'Ávila et al. 2010).

New morphological information given by confocal analyses allows revisiting species described by means of light microscopy (Marigo et al. 2008; D'Ávila et al. 2010; Machado-Silva et al. 2011). D'Ávila et al. (2010) provided the first re-characterization of the reproductive tract of Tanaisia bragai (Santos, 1934) and T. inopina (Freitas, 1951) since the first descriptions of these species in the 1930s and 1950s, respectively. This study also presented the first data on general morphology of the gametes and cells of the glands associated with the reproductive apparatus of these species. The diagnosis of those species states that the male terminal apparatus is reduced to a seminal vesicle; however confocal tomographies allowed detection of the cirrus pouch and cirrus.

It is interesting to note that the confocal microscopy allows the study of specimens preserved in helminthological collections. For example, Machado-Silva et al. (2011) reexamined Schistosoma mansoni Pirajá da Silva, 1908 specimens first described by Pirajá da Silva in Brazil. Confocal microscopy provides details of gross anatomical arrangement of the systems, along with information on cell morphology and tegument ornamentation, which cannot be observed through light microscopy (Mair et al. 1998a, b, 2000; Abdul-Salam \& Sreelatha 2000, 2004; Stewart et al. 2003; Halton 2004; Neves et al. 2004, 2005). In this paper we aimed to re-describe the morphology of the reproductive system of the species $B$. mazzantii, adding new information on the anatomy of the terminal genitalia, as well as on the histological organization of the genital atrium, testes, ovary and vitelline gland, through confocal laser scanning microscopy. 


\section{MATERIAL AND METHODS}

\section{MORPHOLOGICAL ANALYSIS}

The helminths were stained with Mayer's carmalum by the regressive technique proposed by Amato et al. (1991) [ethanol $70 \% 15 \mathrm{~min}$; carmalum $15 \mathrm{~min}$; rapid washing in ethanol $70 \%$; ethanol $70 \%$ added with $0.5 \%$ hydrochloric acid $15 \mathrm{~min}$, ethanol $70 \% 15 \mathrm{~min}$, ethanol $90 \% 15 \mathrm{~min}$, washed twice in absolute ethanol $15 \mathrm{~min}$ each, creosote $24 \mathrm{~h}$ ] and mounted with Canada Balsam on permanent slides. These slides were then observed through a confocal scanning laser microscope (LSM 510 META - laser He/Ne 543, filter LP560; Zeiss) at the Laboratory of Pathology, Oswaldo Cruz Institute, Rio de Janeiro, Brazil.

\section{RESULTS}

Family BRACHYLAIMIDAE Joyeux \& Foley, 1930 Genus Brachylaima Dujardin, 1843

Brachylaima mazzantii (Travassos, 1927)

Harmostomum mazzantii Travassos, 1927: 844.

Brachylaemus (Mazzantia) mazzantii-Travassos \& Khon 1966: 13.

Brachylaima mazzantii - Adriano 2001: 34-35.

SpeCimen EXAMINED. - Host: Columbia livia Gmelin, 1789 (Aves, Columbidae). Locality: Juiz de Fora, Minas Gerais, Brazil.

The helminths were obtained from the helminthological collection of the Department of Zoology, Juiz de Fora Federal University, Minas Gerais, Brazil. The specimens, previously maintained in ethanol $70 \%$, were prepared according to the conventional helminthological techniques, following the protocols proposed by Amato et al. (1991).

\section{REPRODUCTIVE SYSTEM}

The common opening of the reproductive system is located post-equatorial in the middle of a discrete salience (Figs 1AC; 2). The genital pore is pre-testicular (anterior to the anterior testis) and surrounded by a distinct collar of gland cells (Figs 1A, B; 2). On a deeper plane, the genital pore gives place to the male and female openings (Figs 1D; 2A). The reproductive system is situated post-acetabulum and intracaeca. The genital atrium wall is formed by circular muscles fibers. Several glandular cells are visible between the genital atrium wall and the wall of the genital opening, which is also formed by circular muscle fibers. These glandular cells became gradually scarce as the female and male openings became individualized (Figs 1A-E; 2).

\section{Male APPARATUs}

The male genitalia contain a seminal vesicle external to the cirrus pouch, convoluted and filled with sperm. There is a thick-walled bursa that narrows distally prior to opening into an elongate cirrus pouch containing short, unarmed cirrus (Fig. 1). Pars prostatica was not observed. The male germinative lineage is comprised of five cell types. The spermatogonia are the largest cells, with low cytoplasmic content. The nucleus fills the greatest portion of the cell, having an intensely stained heterochromatin. Spermatids are rounded cells arranged in groups, with heterochromatic nucleus of various shapes due to morphological alterations observed during meiosis. The spermatocytes are also arranged in groups. Two stages of development were identified: primary and secondary spermatocytes. Primary spermatocytes are small rounded cells, with small rounded nucleus showing condensed chromatin. After mitotic division, the secondary spermatocytes, which are elongated cells, also arranged in groups, develop. The spermatozoa are arranged in groups and aligned; they can be recognized by its long tails arranged in parallel.

\section{FEMALE APPARATUS}

The female apparatus (Fig. 3) is composed of ovary, ootype, vitelline glands and reservoir, Mehlis' gland, seminal receptacle and uterus. The ovary lies in the region between the anterior and posterior testes (Figs 1F; 3B). Mehlis' gland surrounds the meeting point of the vitelline reservoir's duct, oviduct, uterus and the duct that comes from the seminal receptacle (Figs 3; 4A). Laurer's canal was not observed. The ovary is completely filled by oocytes presumably in different maturation phases because of the size differences among cells. In the posterior region of the ovary, adjacent to the oviduct, there is a round projection. At this site, the oocytes are larger and appear to be free. The oocytes are round cells of relatively small cytoplasmic volume with great central nuclei with prominent nucleoli. Vitelline glands are formed by several acini (Figs 3; 4D), and extend from the beginning of the intestinal caeca bifurcation. The mature vitellocytes have abundant cytoplasm, with numerous spherical cytoplasmic inclusions. These cells are carried through the vitelline duct forming a single row (Fig. 4E) and are stored in the vitelline reservoir.

The uterus ascends to the pharynx and then descends to the genital pore, occupying the body by its bending, when it is replete of eggs (Fig. 4F). The metraterm is prominent, muscular, straight (Fig. 1E). The operculate egg is protected by a shell and the embryo is surrounded by the von Lichtenberg's envelope (Figs 3; 4G).

\section{ALIMENTARY TRACT}

The pharynx is shaped by a dense disposition of radial musculature bundles that connects the inner and outer walls (Fig. 5C, D). A narrow esophagus, circled by esophageal glands (Fig. 5E), connects the pharynx to the intestinal caeca. Covering the inner wall of the intestinal caeca there are numerous microvilli (Fig. 5F).

\section{MusCULATURE OF THE BODY WALL}

The musculature of the body wall is formed by three layers, an outer layer of circular fibers, an intermediate layer of longitudinal fibers and an inner layer of diagonal fibers (Fig. 6CE). The outer layer (Fig. 6C) appears immediately bellow the tegument covered by scales (Fig. 6A-C), which show a variable number of sulci (Fig. 6B). This is the first account for the presence of scales in the tegument of $B$. mazzantii. The intermediate layer is formed by dense longitudinal bundles 

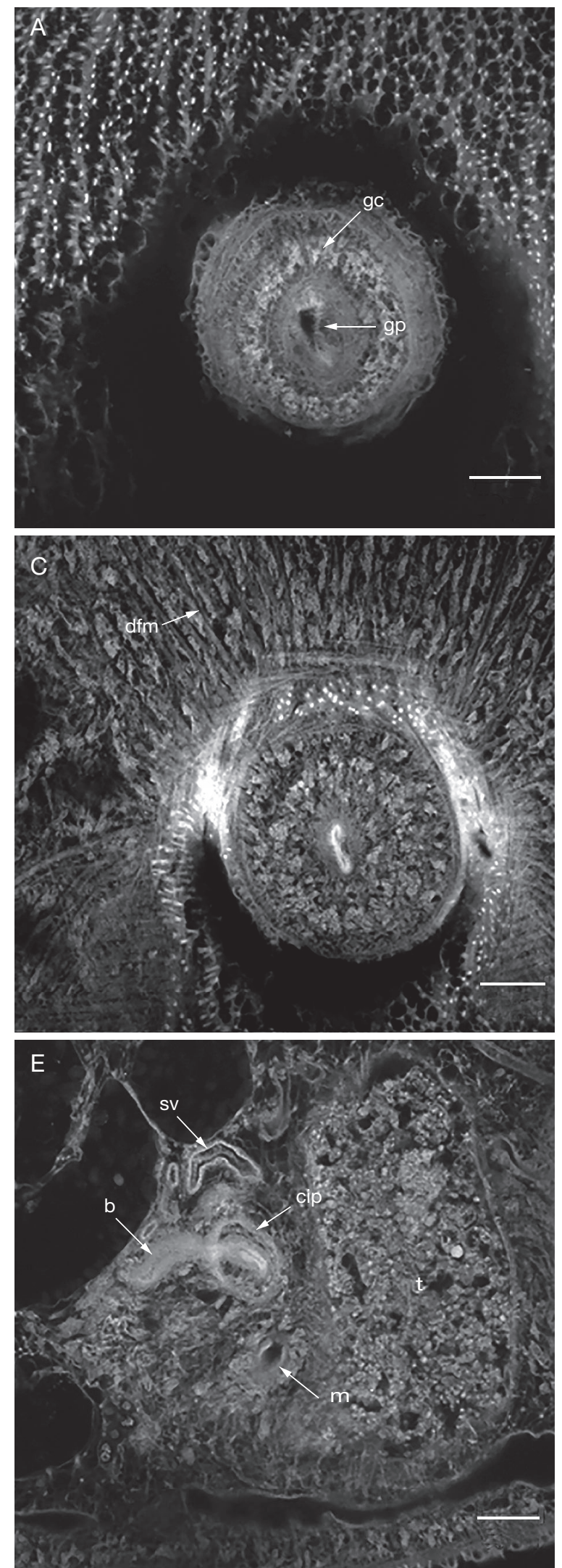
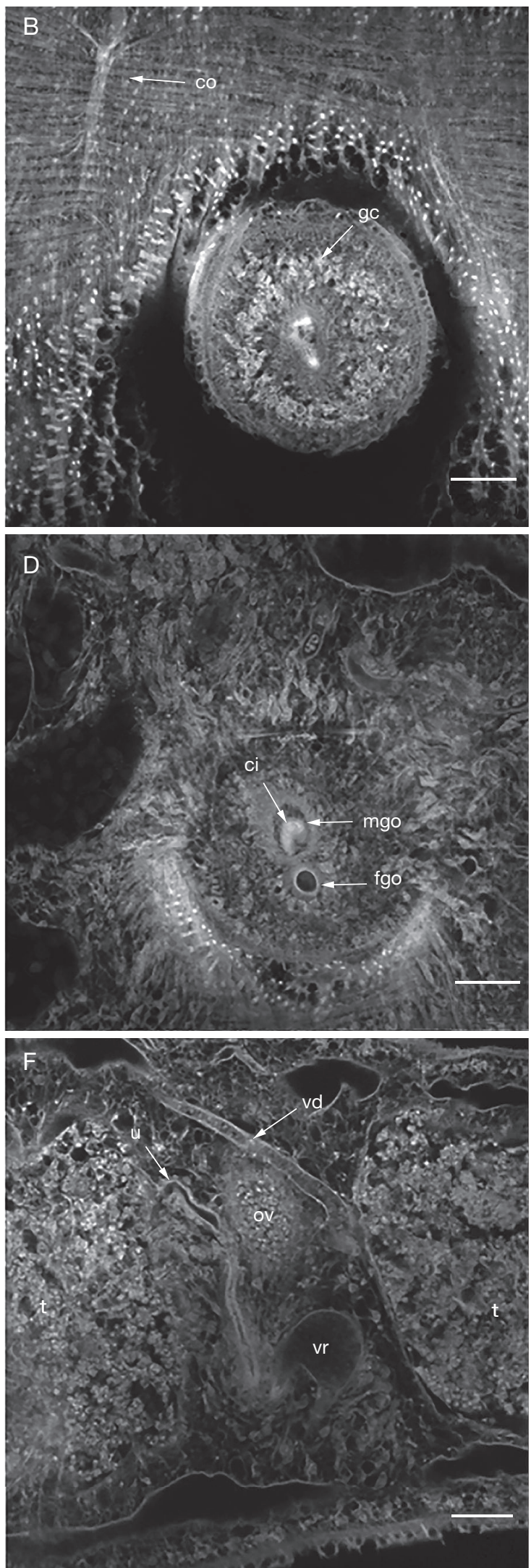

FIG. 1. - Confocal tomographies of the reproductive system of Brachylaima mazzantii (Travassos, 1927): A, gland cells (gc) surrounding the genital pore (gp); B, commissure (co) and gland cells (gc); C, region of the genital opening showing differentiated musculature (dfm); D, female genital opening (fgo), male genital opening (mgo) and unarmed cirrus (ci); E, cirrus pouch (cip), metraterm (m), testes (t), bursa (b) and seminal vesicle (sv); $\mathbf{F}$, vitelline duct (vd), vitelline reservoir $(\mathbf{v r})$, uterus $(\mathbf{u})$, ovary $(\mathbf{o v})$ and testes $(\mathbf{t})$. Scale bars: $50 \mu \mathrm{m}$. 

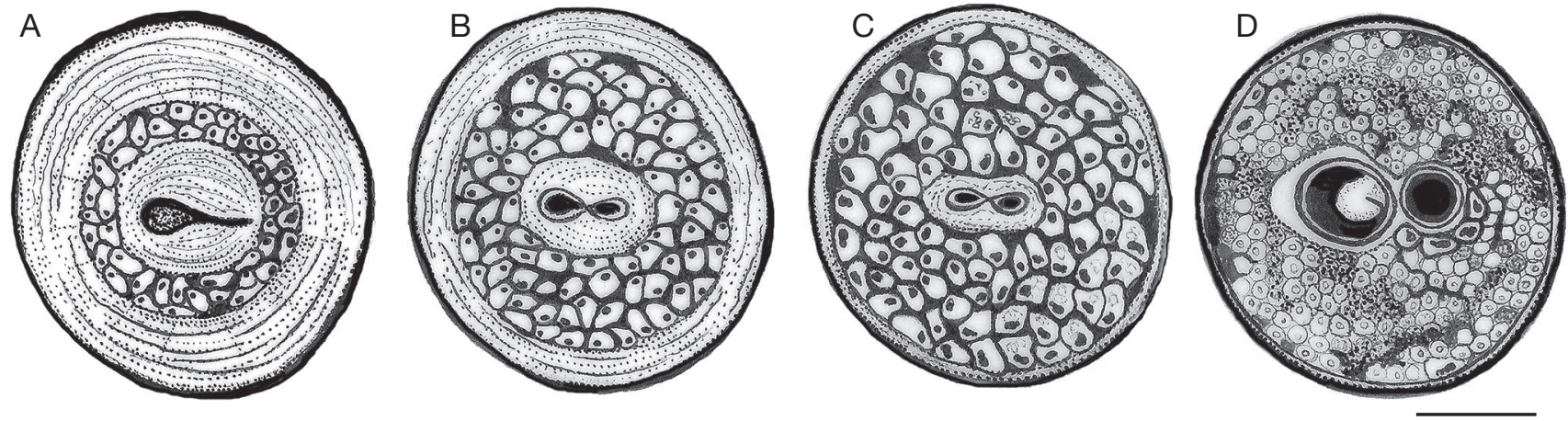

FIG. 2. - Schematic drawings of the genital atrium of Brachylaima mazzantii (Travassos, 1927): A-D, sequential tomographic images starting from the body surface. Scale bar: $5 \mu \mathrm{m}$.

and the inner layer is formed by a mesh of thick diagonal fibers that cross each other in a spaced way (Fig. 6D). Thick bundles of differentiated musculature were also seen (Fig. 6E), probably increasing the stability of the acetabulum (Fig. 6G).

\section{ATTACHMENT APPARATUS}

The oral sucker and acetabulum show a well-developed musculature. It is formed by meridional musculature (Fig. 5A), equatorial bundles surrounding the opening of the suckers (Fig. 5B), and radial musculature connecting the inner and outer surfaces of these structures (Figs 5C; 6G). The main difference related to the musculature of the oral sucker and acetabulum is the disposition of the radial bundles, which are thin, densely arranged and in larger amount on the oral sucker, whereas the acetabulum has fewer, spaced and thick radial fibers. Both structures have numerous papillae in the external and internal surfaces (Figs 5C; 6F-H). They were found isolated or arranged in number of three. The oral sucker and acetabulum differed in the amount of papillae, largely found on the acetabulum and noticed in a less number on the oral sucker.

\section{EXCRETORY AND NERVOUS SYSTEM}

The excretory system of $B$. mazzantii is represented by thin excretory ducts that run along the lateral of the body (Fig. 7A) and by the excretory bladder which is wide, relatively long and bullet-shaped (Fig. 7B). The tomographies also showed parts of the basic flatworm plan of peripheral nerve elements. A pair of ventral nerve cord (Fig. 7C) extends from the cerebral ganglia and ran the length of the worm till the bladder zone. Transverse connectives between the pair of nerve cords were also seen (Figs 1B; 7D).

\section{DISCUSSION}

\section{MORPHOLOGICAL DESCRIPTION OF B. MAZZANTII}

In the present study no immunochemistry was used for the description of the anatomy of $B$. mazzantii, allowing an overview of the organs, glands and ducts of the reproductive, diges- tive and excretory system, along with the musculature of the body wall, the tegument and attachment organs. Brachylaima mazzantii was known only from its original description (Travassos 1927) and the subsequent morphological information given by Travassos (1928) and Lent \& Freitas (1937). Until now, no attempt has been made to address the morphology of this species by means of modern microscopy techniques. In the present study, the information generated with confocal laser scanning microscopy allowed the re-examination of the morphology of this species.

We provided detailed description of the reproductive system and the most significant new data is related to the terminal genitalia. Travassos $(1927,1928)$ did not describe the structure of the male and the female terminal apparatus (Fig. 8). He gave two figures of the cirrus pouch without the representation of the cirrus or other components of the male terminal apparatus (Fig. 3B). He mentioned that the genital opening is located at the anterior testis area and that the cirrus pouch is poorly developed and hardly visible in whole mount preparations. In the present study we characterized the male terminal apparatus, evidencing the presence of a seminal vesicle external to the cirrus pouch containing only a short unarmed cirrus, which agrees with the general pattern of the genus Brachylaima (Segade et al. 2011).

We also described for the first time the presence of a well developed metraterm and the presence of gland cells in the genital atrium of this species. The presence of a metraterm whose walls are lined with gland cells and the presence of gland cells surrounding the terminal genitalia and genital pore region were considered as characteristic traits of members of the Brachylaimidae (Zamparo et al. 2003); however, these glands were not described for the majority of Brachylaima species.

The cells of the vitelline gland disposed in lobed acini were consistent with the description of D'Ávila et al. (2010) for Tanaisia bragai and T. inopina (Eucotylidae), in that the globular cells show large nuclei and conspicuous and eccentric nucleoli, the mature vitellocytes having typical dark-colored spherical cytoplasmic inclusions. Such characteristics of the differentiation of the vitellocytes correspond to the pattern of vitellogenesis observed in other digeneans, monogeneans, 


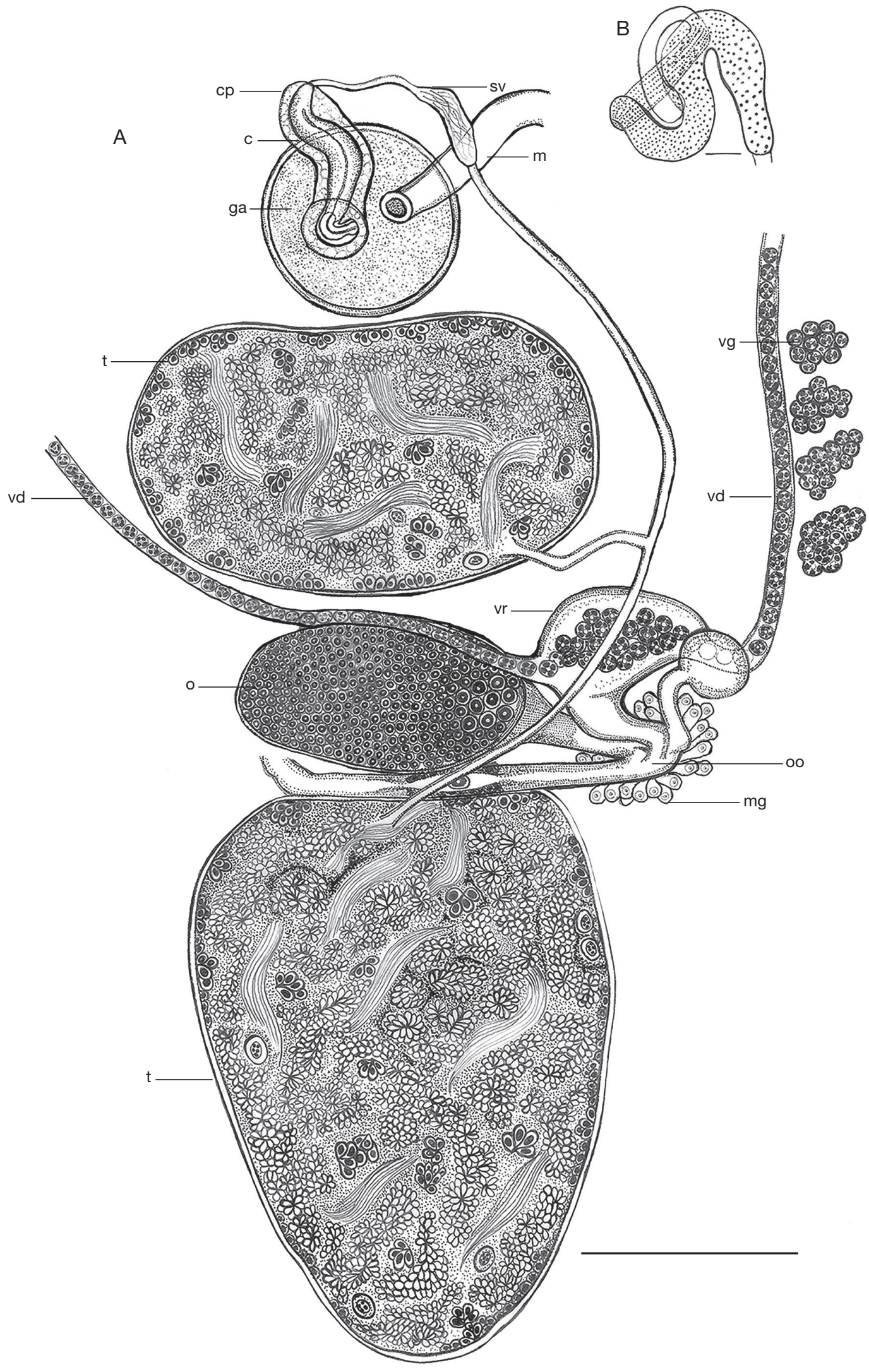

FIG. 3. - Schematic drawings of the reproductive system of Brachylaima mazzantii (Travassos, 1927): A, reconstruction of the reproductive system from the confocal tomographies, showing seminal vesicle $(\mathbf{s v})$, metraterm $(\mathbf{m})$, cirrus $(\mathbf{c})$, cirrus pouch $(\mathbf{c p})$, genital atrium (ga), testes (t), ovary (o), ootype (oo), vitelline duct (vd), vitelline glands (vg) vitelline reservoir (vr), and Mehlis' gland (mg); B, cirrus pouch as first described by Travassos in 1927 (adapted from Lent \& Freitas 1937). Scale bars: A, $0.06 \mathrm{~mm} ; \mathrm{B}, 0.25 \mathrm{~cm}$. 

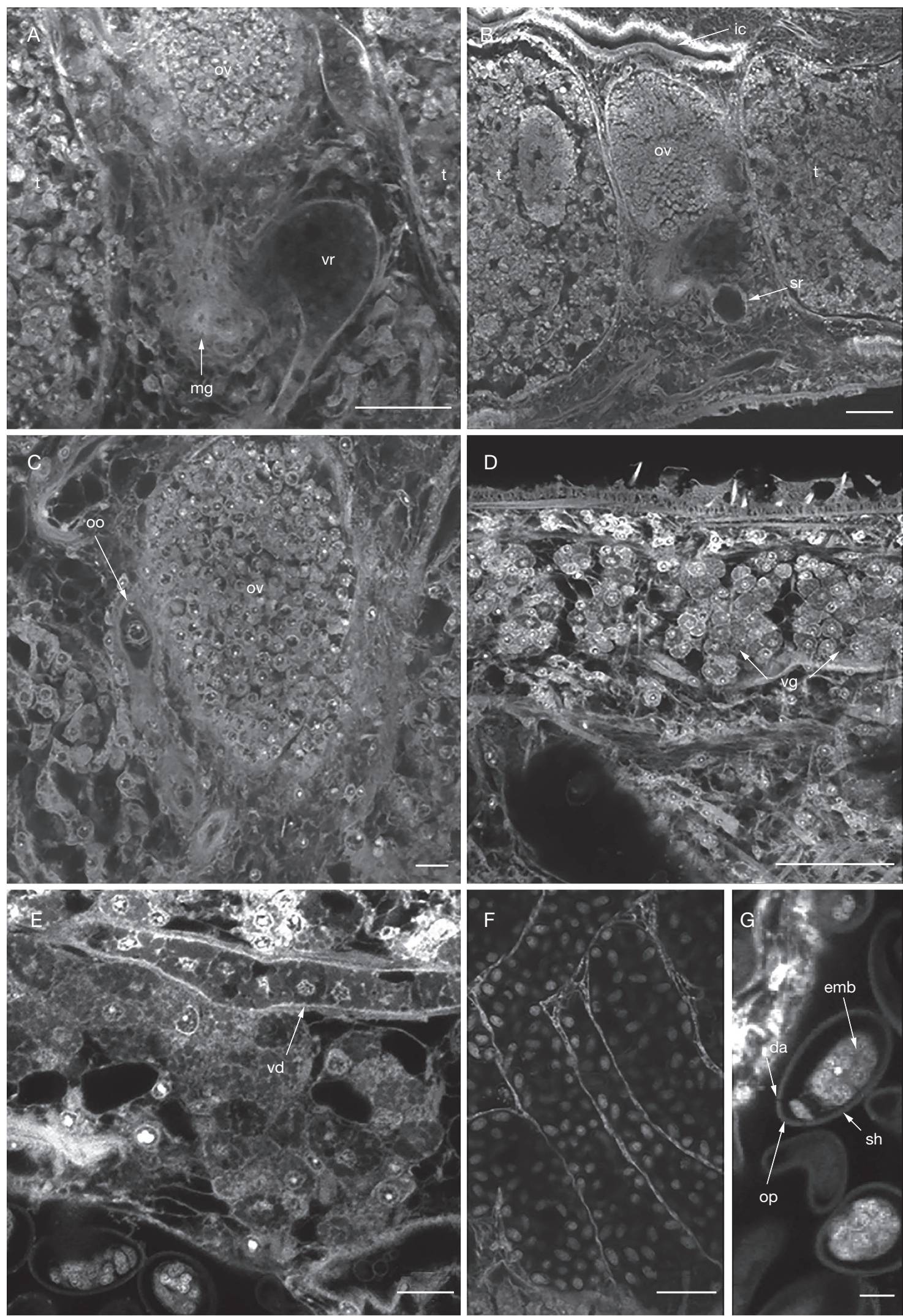

FIG. 4. - Confocal tomographies of the reproductive system of Brachylaima mazzantii (Travassos, 1927): A, Mehlis' gland (mg), vitelline reservoir (vr), ovary (ov) and testes (t); B, ovary (ov), seminal reservoir (sr), testes (t) and intestinal caeca (ic); C, ovary (ov) and ootype (oo); D, vitelline glands (vg) forming lobed acini; $\mathbf{E}$, vitelline duct (vd) showing vitelline cells inside forming a single row; $\mathbf{F}$, uterus full of eggs; $\mathbf{G}$, egg, revealing the embryo (emb), eggshell (sh), operculum (op) and discontinuity area (da) in the eggshell. Scale bars: A, B, D, F, $50 \mu \mathrm{m} ; \mathrm{C}, \mathrm{E}, 10 \mu \mathrm{m} ; \mathrm{G}, 5 \mu \mathrm{m}$. 

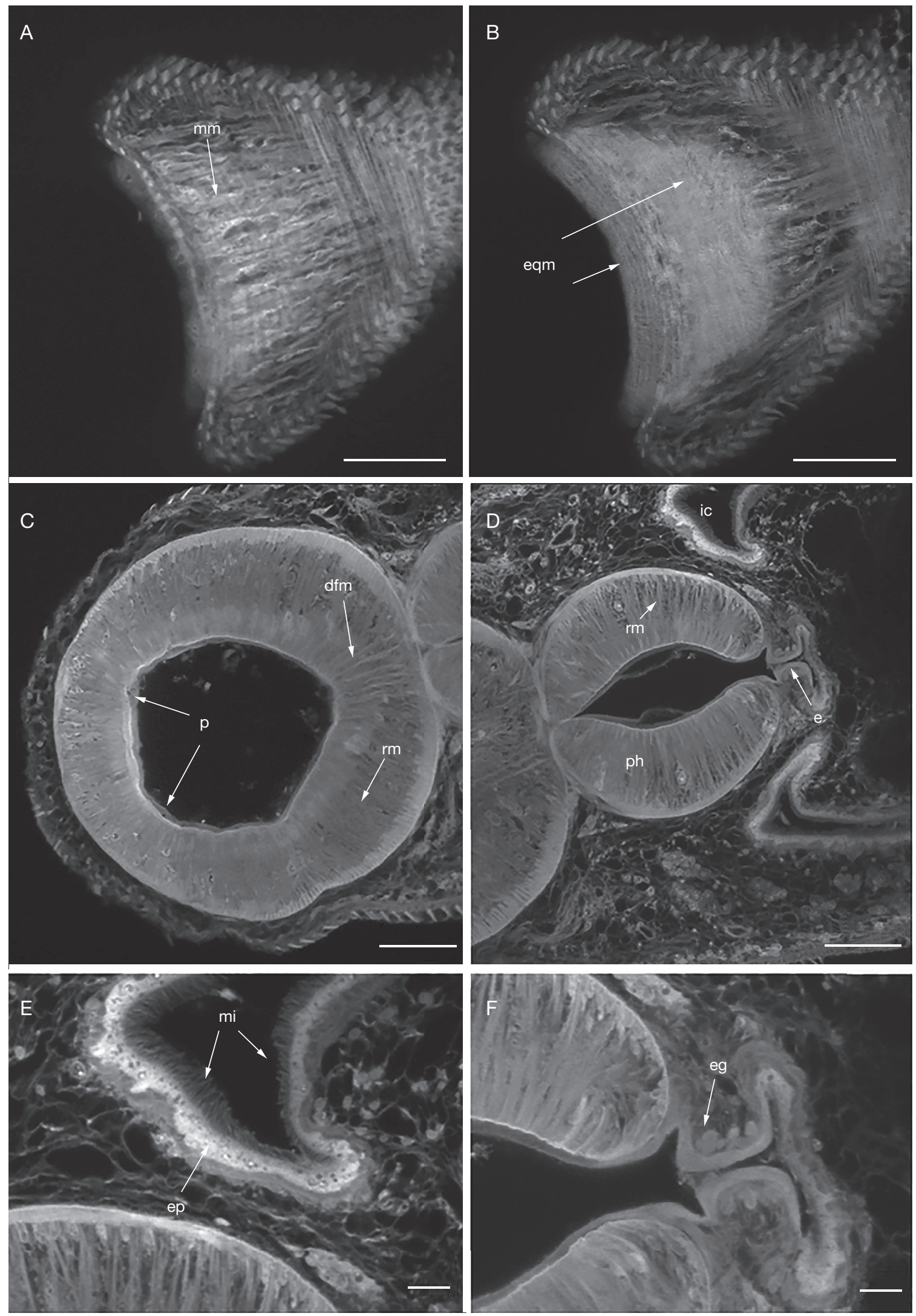

FIG. 5. - Confocal tomographies showing the anterior region of Brachylaima mazzantii (Travassos, 1927): A, image showing the meridional musculature (mm); B, equatorial musculature (eqm); C, radial musculature ( $\mathbf{r m})$, papillae (p) on the surface of the oral sucker and differentiated musculature (dfm) making the transition between mouth and pharynx (pre-pharynx); D, pharynx (ph), radial musculature (rm), esophagus (e), and intestinal caeca (ic); E, detail of the intestinal caeca, revealing numerous microvilli (mi), and the epithelium (ep); F, esophageal glands (eg) circling the esophagus. Scale bars: A-D, $50 \mu \mathrm{m} ; \mathrm{E}, 10 \mu \mathrm{m}$. 

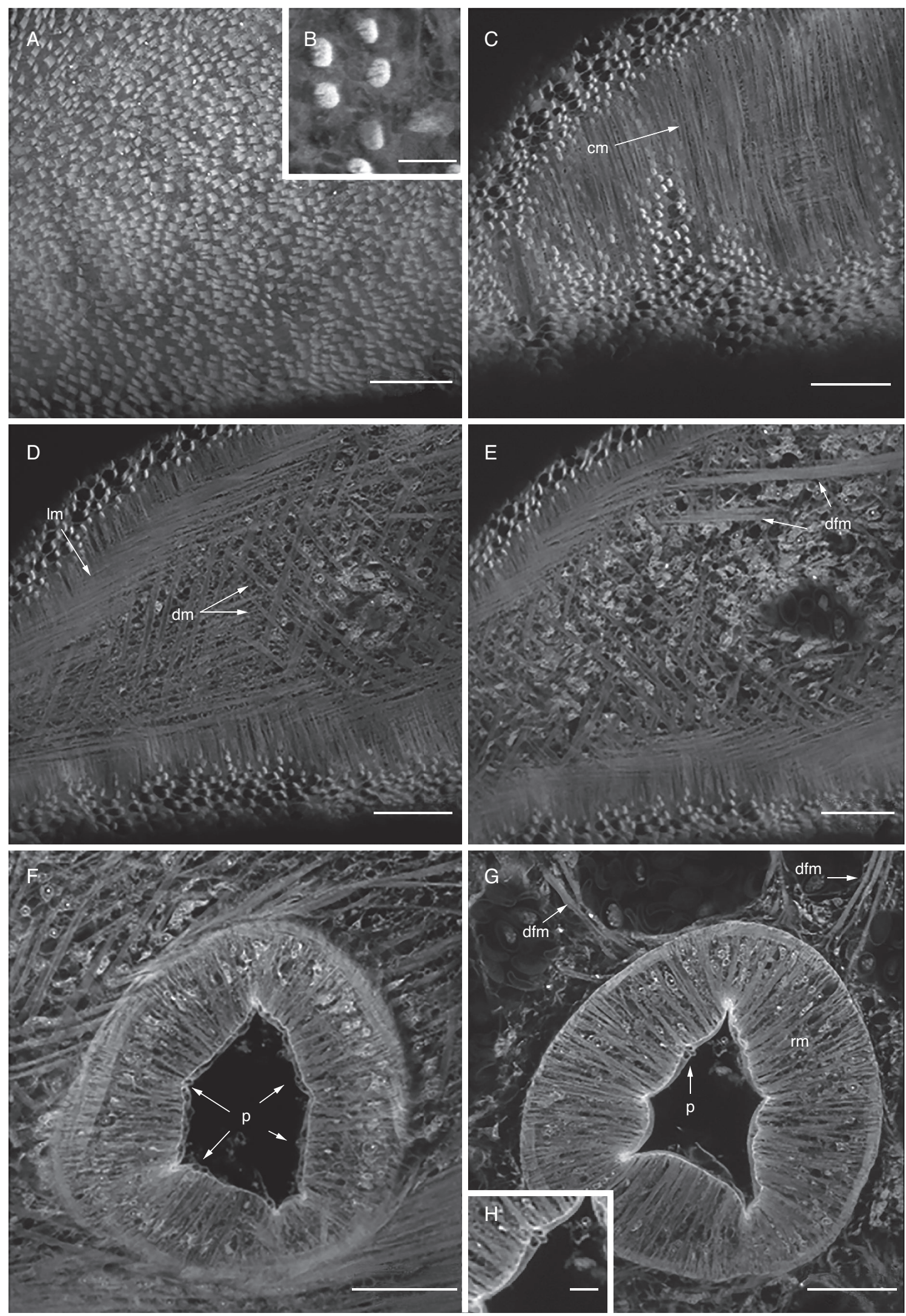

FIG. 6. - Confocal tomographies of tegument, musculature of the body and acetabulum of Brachylaima mazzantii (Travassos, 1927): A, tegument covered by many scales; B, scales; C, circular musculature (cm); D, longitudinal (Im) and diagonal musculature (dm); E, two differentiated muscle bundles (dfm); F, surface of acetabulum featuring many papillae (p); G, papillae (p), radial musculature (rm) and differentiated musculature (dfm) supporting the acetabulum; $\mathbf{H}$, papillae. Scale bars: A-G, $50 \mu \mathrm{m} ; \mathrm{H}, 10 \mu \mathrm{m}$. 

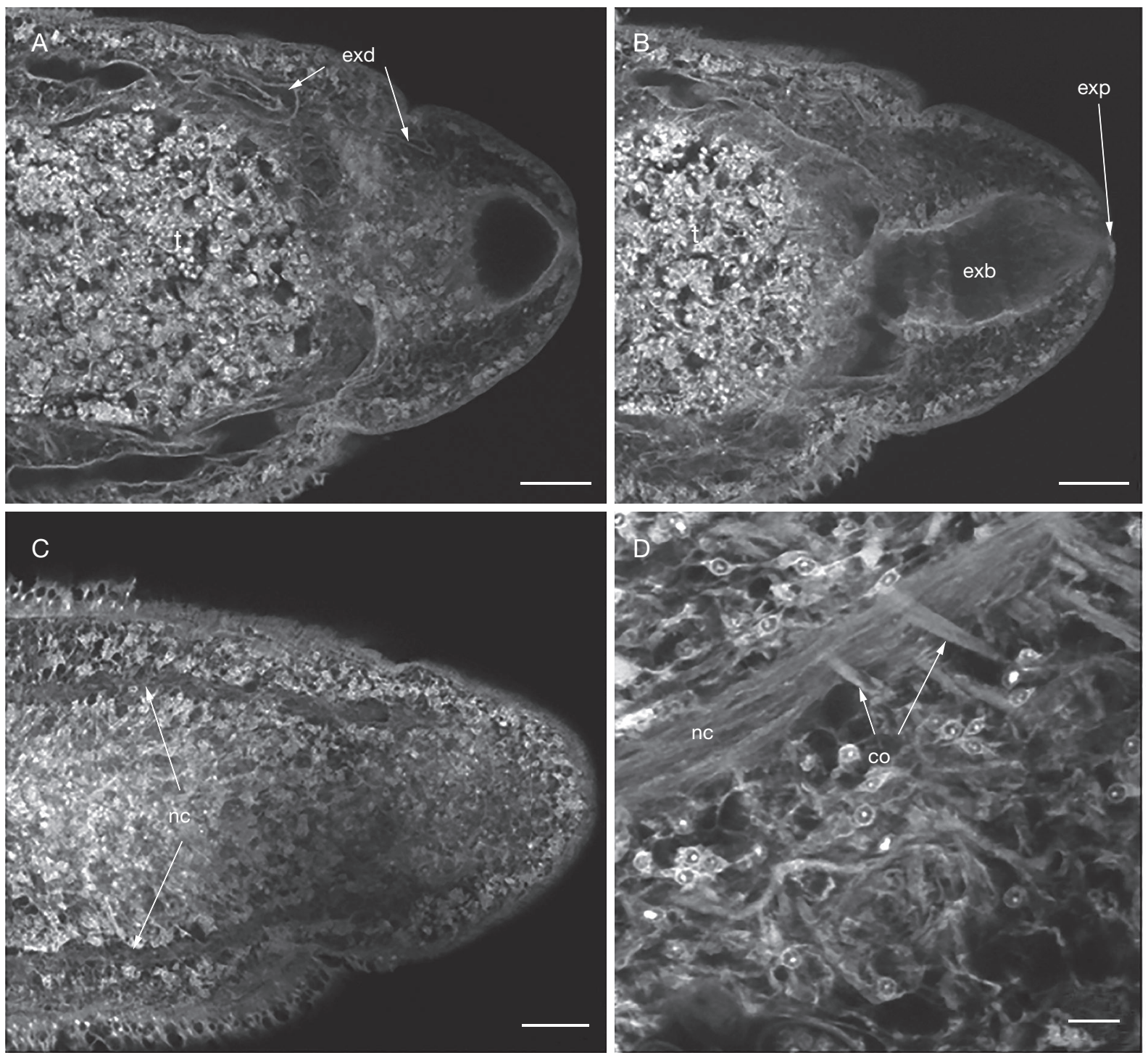

FIG. 7. - Confocal tomographies of the excretory and nervous system of Brachylaima mazzantii (Travassos, 1927): A, excretory ducts (exd), testes (t); B, excretory bladder (exb), excretory pore (exp), and testes (t); C, longitudinal nervous cord (nc); D, commissures (co) originated from the nervous cord (nc). Scale bars: $\mathrm{A}-\mathrm{C}, 50 \mu \mathrm{m} ; \mathrm{D}, 10 \mu \mathrm{m}$.

cestodes and free-living neophorans (Swiderski \& Xylander 2000; D'Ávila et al. 2010).

The present study also revealed some traits concerning other systems, unnoticed by Travassos $(1927,1928)$ and Lent $\&$ Freitas (1937), as the shape and relative position of the excretory vesicle and the tegument ornamented with scales. Travassos (1927) gave no description of the excretory system or the tegument of B. mazzantii. Lent \& Freitas (1937) erroneously reported that the tegument of this species lacks ornamentation.

The organization of the muscle system of $B$. mazzantii described in the present work shows patterns concordant with the description of other digeneans, after re-examination by modern microscopy techniques (Mair et al. 1998a, b, 2000; Butcher et al. 2002; Kumar et al. 2003; Šebelova et al. 2004; Gonzalez-Moreno \& Gracenea 2006; Terenina et al. 2006; Segade et al. 2011). The general organization of the musculature in the body wall, being formed by the circular, longitudinal and diagonal layers appears to be a pattern very conserved among digeneans (Kumar et al. 2003; Šebelova et al. 2004; D'Ávila et al. 2010).

The oral sucker is both an attachment organ and a feeding structure, being responsible for a suction force generated by the action of its musculature (Smyth \& Halton 1983). On the acetabulum, some specialized fibers probably anchor this structure to the body wall (Tolstenkov et al. 2010). We observed sensory papillae on the oral sucker and acetabulum of adult B. mazzantii. This information is concordant with studies on other brachylaimids (Butcher et al. 2002; GonzalezMoreno \& Gracenea 2006; Segade et al. 2011). The presence of tegumental sensory papillae was mostly documented on cercariae (Wagner 1961; Robson \& Erasmus 1970; Šebelova et al. 2004; Gonzalez-Moreno \& Gracenea 2006; Segade et al. 2011) and metacercariae (Poddubnaya et al. 2010). In adults, 
papillae types and arrangement has been lesser emphasized, although considered as an important additional taxonomic trait (Butcher et al. 2002; Mata-Lopez \& Leon-Regagnon 2006).

Since Digenea is characterized by a substantial interspecific homogeneity of the morphological traits used for species discrimination, the employment of new microscopy techniques may reveal characters that can be useful for taxonomy. Ultimately, the new character observed may even promote taxonomic changes (Zamparo et al. 2003).

The present new data on the morphology of B. mazzantii, allowed the re-examination of this species. The main advantage of using confocal microscopy to study the morphology of digeneans is the fact that with only one technique it is possible to examine the anatomy, cell morphology and surface topography. Confocal tomographies show much more detail than light microscopy images, and allow getting information on cell morphology, usually achieved only by histological techniques, along with some information on tegument ornamentation, usually obtained through scanning electron microscopy. The accumulation of information on the morphology of different digenean species will allow future comparative confocal studies which may ultimately contribute to the better resolution of the taxonomy and systematics of this group.

\section{TAXONOMIC CONSIDERATIONS}

The genus Brachylaima was originally proposed by Dujardin (1843), based upon $B$. advena Dujardin, 1845 and other species. Later, Dujardin (1845) reduced Brachylaima to the subgeneric rank, changing the spelling to Brachylaimus which was adopted by some authors (Baird 1853; Stossich 1889; 1891; 1895; Gedoelst 1919; Baylis 1932). Blanchard (1847) corrected the spelling Brachylaimus to Brachylaemus and restored it to the generic rank, taking Fasciola cylindracea Zeder, 1800 and Distoma variegatus as types. Stiles \& Hassall (1898) returned the name to Brachylaima and stated that $B$. advena should remain as the type of the genus Brachylaemus, since neither F. cylindracea nor $D$. variegatus were originally mentioned by Dujardin (1843) when the genus was proposed. Nonetheless, several species were ascribed to Brachylaemus and Brachylaimus and these spellings remained in use as generic names for a long time (Billet 1892, 1896; Lotti 1906; Boulenger 1913; Joyeux \& Foley 1930; Krull 1934; Balozet 1937; Sandground 1938; Haukisalmi et al. 1994). Since the works of Yamaguti (1971, 1975), the accepted spelling of the genus has been Brachylaima due to its common usage and nomenclatural stability (Pojmańska 2002). This spelling is now in use for several species previously ascribed to Brachylaemus, Brachylaimus and Harmostomum, including B. mazzantii (Adriano et al. 2001; Taroda et al. 2013; Naupay et al. 2014), which was ascribed to Brachylaima without further revision.

In the present study we observed in B. mazzantii the presence of a very short esophagus. This structure is considered to be absent (Dujardin 1843) or practically absent (Pojmańska 2002) in species of Brachylaima. However, our results indicate that the esophagus may have been unnoticed by previous authors who examined other species of Brachylaima by means of light microscopy. The presence in $B$. mazzantii of a small esophagus

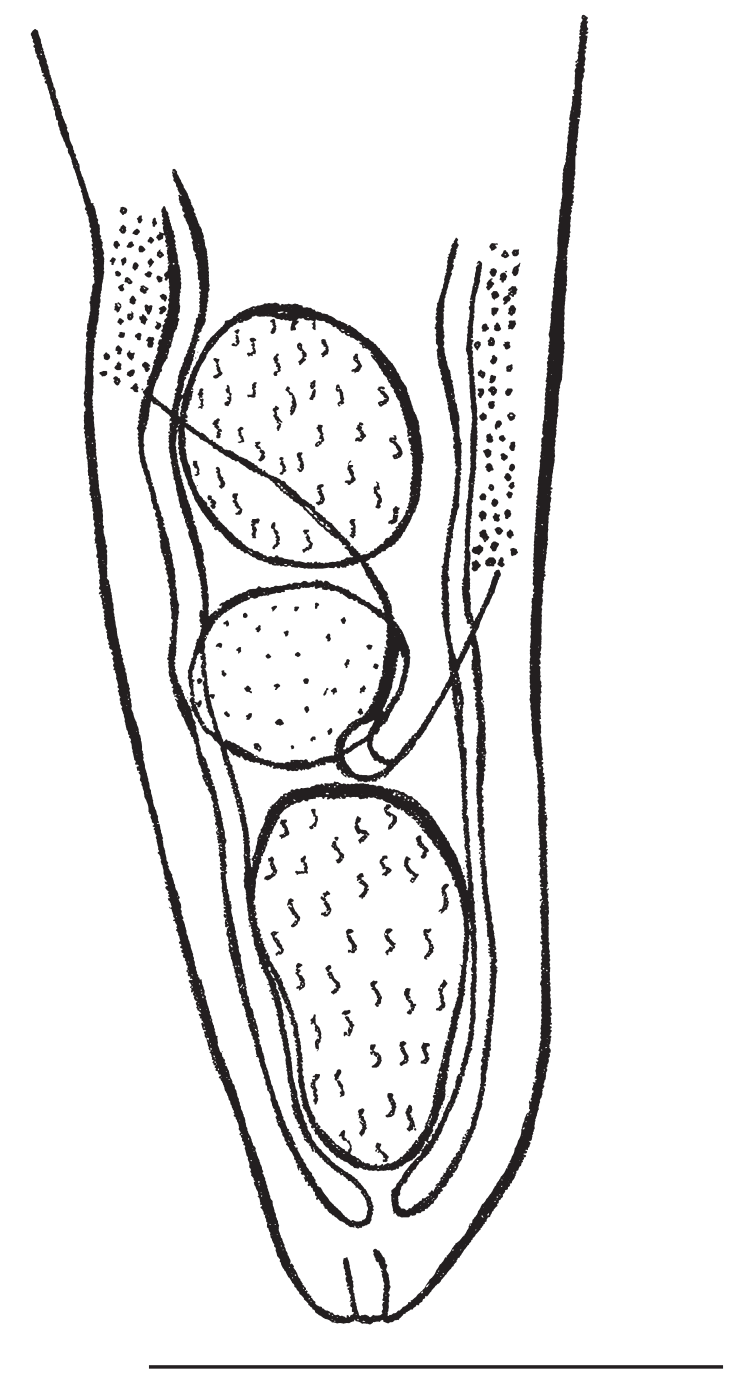

FIG. 8. - Reproductive system of Brachylaima mazzantii (Travassos, 1927) as first described by Travassos in 1927 (adapted from Lent \& Freitas 1937). Scale bar: $1 \mathrm{~mm}$.

along with small suckers and the vitelline fields exceeding the acetabular zone is not in accordance with the diagnosis of the subfamily Brachylaiminae. The presence of a small esophagus, small suckers and filiform body is characteristic of Ityogoniminae Yamaguti, 1958. However, B. mazzantii do not present a prepharynx and its body is elongate rather than filiforme. Some other species ascribed to Brachylaima also have elongate rather than the typical oval body [ie. Brachylaima degiustii Nasir \& Rodrigues, 1966; B. smile (Jonhston, 1913); B. delecta Cribb, 1992; B. sandarsae Cribb, 1992; B. brindabellensis Cribb, 1992; B. nicolli Witenberg, 1925; B. virginianus (Dickerson, 1930); B. syrmatici Yamaguti, 1935; B. pulchellum (Johnston, 1917)]. The position of the ventral sucker as well as the position of the genital pore on the ventral surface of the body and anterior to the anterior testis does not allow ascribing this species to the genus Ityogonimus Luhe, 1899. The extension of the uterus exceeding the acetabular zone anteriorly and reaching posteriorly the level of the anterior testis, the position of the vitellarium exceeding the acetabular zone, as well 
as the relative position of the suckers do not allows ascribing this species to the genus Scaphiostomum Braun, 1901. The results of the present study revealed that $B$. mazzanti shows morphological traits very similar to those of $B$. advena, the type species of genus Brachylaima, with the exception of the relative size of the suckers, the presence of a short esophagus and the extension of the vitellaria (Travassos \& Kohn 1966; Freitas et al. 1967). Thus, we believe that this species should be maintained in the subfamily Brachylaiminae, genus Brachylaima and we suggest that the diagnosis of this genus should be amended, including: body usually armed with fine spines or small scales. Suckers usually well developed but sometimes small. Esophagus short or practically absent. Vitelline fields lateral between ventral sucker and anterior testis, sometimes exceeding the acetabular field.

We also observed that the tegument of $B$. mazzantii is covered with scales rather than with spines as described for $B$. advena (Travassos \& Khon, 1966; Freitas et al., 1967) and as stated in the characterization of Brachylaiminae (Pojmańska, 2002). As many species of Brachylaima were poorly described, the reexamination of the tegument ornamentation by means of scanning electron microscopy or confocal scanning microscopy is necessary to improve the diagnosis of this genus.

The cirrus is another trait which was considered absent in some species of Brachylaima by Dujardin (1843), including the type species $B$. advena. This later was examined by Freitas et al. (1967) who observed the presence of post-equatorial, pre-testicular and well formed cirrus pouch with unarmed cirrus. Travassos $(1927,1928)$ described the cirrus pouch of B. mazzantii as rudimentary and did not describe the cirrus, leading to some uncertainty about the presence of this structure in this species. These structures are difficult to see by light microscopy and it would be of interest reexamining other species of Brachylaima for which the cirrus is considered absent.

\section{Acknowledgements}

The authors wish to acknowledge Marcelo Pelajo Machado from Department of Patology, Oswaldo Cruz Institute, Rio de Janeiro, Brazil for the access to the confocal microscope as well as Sueli de Souza Lima from Department of Zoology, Federal University of Juiz de Fora, who kindly ceded the specimens studied. We also wish to acknowledge Dr Teresa Pojmańska for their invaluable comments and suggestions on this manuscript. This work was sponsored by FAPEMIG (Fundação de amparo a Pesquisa do Estado de Minas Gerais).

\section{REFERENCES}

Abdul-Salam J. \& SReelatha B. S. 2000. — Surface morphology of Probolocoryphe uca (Sarkisian, 1957) (Digenea, Microphallidae) from Kuwait Bay. Systematic Parasitology 46: 209-214. https:// doi.org/10.1023/A:1006394104481

Abdul-Salam J. \& SREelatha B. S. 2004. - Description and surface topography of the cercaria of Austrobilharzia sp. (Digenea: Schistosomatidae). Parasitology International 53: 11-21. https:// doi.org/10.1016/j.parint.2003.10.001
Adriano E. A., Thyssen P. J. \& Cordeiro N. S. 2001. — Brachylaima mazzantii (Trematoda): first record in Zenaida auriculata (Aves: Columbidae). Boletin Chileno de Parasitologia 56 (1-2): 34-35.

Amato J. F. R., Boeguer W. A. \& Amato S. B. 1991. - Protocolos para laboratório - coleta e processamento de parasitos do pescado. Imprensa Universitária, Universidade Federal Rural do Rio de Janeiro, Seropedica, $81 \mathrm{p}$.

BAIRD W. 1853. - Catalogue of the species of Entozoa or intestinal worms, contained in the collection of the British Museum, $132 \mathrm{p}$.

BALOZET L. 1937. — Rôle pathogène de Brachylaemus suis. Bulletin de l'Académie vétérinaire de France 10 (1): 171-175.

BAYLIS H. A. 1932. - A list of worms parasitic in Cetacea. Discovery Reports 6: 395-418.

Billet A. 1892. - Sur quelques trématodes parasites des bœufs du Tonkin. (Note préliminaire). Séances et Mémoires de la Société de Biologie: 613-615.

Billet A. 1896. - Notes sur la faune du haut-Tonkin II. Sur quelques distomes. Bulletin scientifique de la France et de la Belgique 28: 283-309.

BLANCHARD M. E. 1847. - Recherches sur l'organisation des vers. Annales des Sciences naturelles 8: 271-342.

Boulenger G. A. 1913. - The Snakes of Europe. XI. Parasites. Methuen \& CO. London: 107-116. http://www.biodiversitylibrary.org/bibliography/4255

Butcher A. R., Brealey J. K., Grove D. I. \& Dymock R. B. 2002. - Brachylaima cribbi (Digenea: Brachylaimidae): scanning electron microscopical observations of the life cycle stages. Journal of Helminthology 76: 207-215. https://doi.org/10.1079/ JOH2002119

Costa H. M. A. \& Freitas M. G. 1959. - Novos achados helmintologicos em animais domésticos de Minas Gerais. Arquivos da Escola Superior de Veterinária 12: 293-297.

Costa H. M. A., Leite A. C. R., Guimarães M. P. \& Lima W. S. 1986. - Distribuição de helmintos parasitos de animais domesticos no Brasil. Arquivos Brasileiros de Medicina Veterinária e Zootecnia 38 (4): 465-579.

D’Ávila S., Manso P. P. A., Bessa E. C. A., Rodrigues M. L. A. \& DIAS R. J. P. 2010. — Gross anatomy of the musculature and a new description of the reproductive system of Tanaisia bragai and Tanaisia inopina (Trematoda: Eucotylidae) analyzed by confocal laser scanning microscopy. Acta Zoologica 91: 139-149. https:// doi.org/10.1111/j.1463-6395.2008.00393.x

DUJARDIN F. 1843. - Mémoire sur les helminthes des musaraingnes et en particulier sur les trichosomes, les distomes et les taenias, sur leurs métamorphose et leurs transmigrations. Annales des Sciences naturelles 20: 330-343.

DUJARDIN F. 1845. - Histoire naturelle des helminthes ou vers intestinaux. Nouvelles suites à Buffon. Librarie encyclopédique de Roret, Paris. 54 p. https://doi.org/10.5962/bhl.title.10123

Freitas J. F. T., Kohn A. \& Ibanez N. H. 1967. — Sobre as especies de Brachylaemus (Brachylaemus) Dujardin, 1843 (Trematoda). Memórias do Instituto Oswaldo Cruz 65 (1): 41-61. https://doi. org/10.1590/S0074-02761967000100006

GedOELST L. 1919. - Une espéce nouvelle de Anchitrema. Séances et Mémoires de la Societé de Biologie: 1250-1252.

Gonzalez-Moreno O. \& Gracenea M. 2006. — Life cycle and description of a new species of Brachylaimid (Trematoda: Digenea), in Spain. Journal of Parasitology 92 (6): 1305-1312. https://doi.org/10.1645/GE-821R.1

Halton D. W. 2004. — Microscopy and the helminth parasite. Micron 35: 361-390. https://doi.org/10.1016/j.micron.2003.12.001

Haukisalmi V., Henttonem H. \& Mikkonen T. 1994. — Parasitism by gastrointestinal helminthes in the shrews Sorex araneus and S. caecutiens. Special Publication of Carnegie Museum of Natural History. Advances in the Biology of shrews 18: 97-102.

JoyeuX CH. \& Foley H. 1930. — Les helminthes des meriones Shawi shawi Rozet dans le nord de l'Algerie. Bulletin de la Societé zoologique de France 55 (5): 353-374. 
KRULL W. H. 1934. - New experimental hosts for Brachylaemus virginiana. Journal of the Washington Academy of Sciences 24 (11): 483-485.

Kumar D., McGeown J. G., Reynoso-Ducoing O., Ambrosio J. R. \& FAIRWETHER I. 2003. - Observations on the musculature and isolated muscle fibres of the liver fluke, Fasciola hepatica. Parasitology 127: 457-473. https://doi.org/10.1017/ S0031182003003925

LENT H. \& Freitas J. F. 1937. — Pesquisas helminthologicas realizadas no estado do Para. I. Trematoda: Fascioloidea. Memórias do Instituto Oswaldo Cruz 32 (3): 449-460. https://doi.org/10.1590/ S0074-02761937000300008

LOTTI R. 1906. - Contributo alla conoscenza dei Distomi parassiti nell'intestino dei pesci. Boletino della Societá Zoologica Italiana 7: 226-227.

Machado-Silva J. R., Neves R. H. \& Gomes D. C. 2011. Schistosoma mansoni specimens first described by Piraja da Silva in Brazil (1908) re-examined by confocal laser sccaning microscopy. Revista da Sociedade Brasileira de Medicina Tropical 44: 331-333. https://doi.org/10.1590/S0037-86822011005000027

Mair G. R., Maule A. G., Day T. A. \& Halton D. W. 2000. A confocal microscopical study of the musculature of adult Schistosoma mansoni. Parasitology 121: 163-170. https://doi. org/10.1017/S0031182099006174

Mair G. R., Maule A. G., Shaw C. \& Halton D. W. 1998a. Muscling on parasitic flatworms. Parasitology Today 14: 73-76. https://doi.org/10.1016/S0169-4758(97)01182-4

Mair G. R., Maule A. G., Shaw C., Johnston C. F. \& Halton D. W. 1998b. - Gross anatomy of the muscle systems of Fasciola hepatica as visualized by phalloidin-fluorescence and confocal microscopy. Parasitology 117: 75-82. https://doi.org/10.1017/ S0031182098002807

Marigo J., Vicente A. C. P., Valente A. L. S., Measures L. \& SANTOS C. P. 2008. - Redescription of Synthesium pontoporiae n. comb. with notes on $S$. tursionis and $S$. seymouri n. comb. (Digenea: Brachycladiidae Odhner, 1905). Journal of Parasitology 94: 505-514. https://doi.org/10.1645/GE-1306.1

Martins J. W. \& Freitas M. G. 1975. — Lista de helmintos parasitos de animais domésticos da regiáo geoeconômica de Brasília e de outras regióes de Goiás. Arquivos da Escola Superior de Veterinária 27 (3): 309-324.

MatA-Lopez R. \& LeON-Regagnon V. 2006. - Comparative study of the tegumental surface of several species of Gorgoderina Looss, 1902 (Digenea: Gorgoderidae), as revealed by scanning electron microscopy. Comparative Parasitology 73 (1): 24-34. https://doi.org/10.1654/4186.1

Naupay-Igreda A., Pinedo-Reyes K. M. \& Robles-Noriega K. 2014 - First record of Brachylaima mazzantii Travassos, 1927 in domestic pigeon (Columbia livia) in Peru. Neotropical Helminthology 8 (2): 463-467.

Neves R. H., Biolchini C. L., Machado-Silva J. R., Carvalho J. J., Branguinho T. B., Lenzi H. L., Hulstijn M. \& Gomes D. C. 2005. - A new description of the reproductive system of Schistosoma mansoni (Trematoda: Schistosomatidae) analysed by confocal laser scanning microscopy. Parasitology Research 95: 43-49. https://doi.org/10.1007/s00436-004-1241-2

Neves R. H., Costa-Silva M., Martinez E. M., Branquinho T. B., Oliveira R. M. F., Lenzi H. L., Gomes D. C. \& MachadoSiLVA J. R. 2004. - Phenotypic plasticity in adult worms of Schistosoma mansoni (Trematoda: Schistosomatidae) evidenced by brightfield and confocal laser scanning microscopies. Memórias do Instituto Oswaldo Cruz 99: 131-136. https://doi.org/10.1590/ S0074-02762004000200003

Poddubnaya L. G., Mishina E., Zhokhov A. E. \& Gibson D. I. 2010. - Ultrastructural features of the tegumental surface of a new metacercaria, Nematostrigea sp. (Trematoda: Strigeidae), with a search for potential taxonomically informative characters. Systematic Parasitology 75 (1): 59-73. https://doi.org/10.1007/s11230-009-9207-5
POJMAŃSKA T. 2002. — Superfamily Brachylaimoidea Joyeux \& Foley, 1930, in Gibson D. I., Jones A. \& Bray R. A. (Eds), Keys to the Trematoda. CAB International and The Natural History Museum, London: 31-16.

RoBSON R. T. \& ERASMUS D. A. 1970. - The ultrastructure, based on stereoscan observations, of the oral sucker of the cercaria of Schistosoma mansoni with special reference to penetration. Zeitschrift zür Parasitenkunde 35 (1): 76-86.

SANDGROUND J. H. 1938. - Some parasitic worms in the helminthological collection of the Museum of Comparative Zoology. Bulletin of the Museum of Comparative Zoology 85 (2): 35-48.

Šebelova S., Stewart M. T., Mousley A., Fried B., Marks N. J. \& Halton D. W. 2004. - The musculature and associated innervation of adult and intramolluscan stages of Echinostoma caproni (Trematoda) visualized by confocal microscopy. Parasitology Research 93 (3): 196-206. https://doi.org/10.1007/ s00436-004-1120-x

Segade P., Crespo C., Garcia N., Garcia-Estevez J. M., Arias C. \& IgLESIAS R. 2011. - Brachylaima aspersae n. sp. (Digenea: Brachylaimidae) infecting farmed snails in NW Spain: Morphology, life cycle, pathology, and implications for heliculture. Veterinary Parasitology 175 (1): 273-286. https://doi.org/10.1016/j. vetpar.2010.10.026

Silva C. C., Mattos-Junior D. G. \& Ramires P. M. 1990. Helmintos parasitas de Columba livia (Gm) no municipio de São Gonçalo, Rio de Janeiro. Arquivos Brasileiros de Medicina Veterinária e Zootecnia 42 (5): 391-394.

SMYTH J. D. \& Halton D. W. 1983. - The physiology of trematodes. Cambridge University Press, $432 \mathrm{p}$.

Stewart M. T., Mousley A., KoubKova B., Šebelova S., Marks N. J. \& Halton D. W. 2003. - Gross anatomy of the muscle systems and associated innervation of Apatemon cobitidis proterorhini metacercaria (Trematoda: Strigeidae), as visualized by confocal microscopy. Parasitology 126: 273-282. https://doi. org/10.1017/S0031182002002780

Stiles C. W. \& Hassall A. 1898. - Notes on parasites. 48. An inventory of the genera and subgenera of the trematode family Fasciolidae. Archives de Parasitologie 1: 81-99.

STOSsich M. 1889. - I distomi degli anfibi. Boletino della Societá Adriatica di Scienze Naturali 13: 59-73.

STOSsich M. 1891. — I distomi degli Uccelli. Boletino della Societá Adriatica di Scienze Naturali 40: 143-196.

STOSsich M. 1895. - I distomi dei rettili. Boletino della Societá Adriatica di Scienze Naturali 16: 213-235.

SWIDERSKI Z. \& XYLANDER W. E. R. 2000. - Vitellocytes and vitellogenesis in cestodes in relation to embryonic development, egg production and life cycle. International Journal for Parasitology 30: 805-817. https://doi.org/10.1016/S0020-7519(00)00066-7

Taroda A., Barros L. D., Zulpo D. L., Cunha I. A. L., Paiva M. C. D. C., Sammi A. S., Santos J. R., Yamamura M. H., VidotTo O. \& GARCIA J. L. 2013. - Occurrence of gastrointestinal and renal helminthes in Zenaida auriculata (Des Murs, 1847) trap captured from Brazil. Revista Brasileira de Parasitologia Veterinára 22 (3): 415-419. https://doi.org/10.1590/S198429612013000300016

Terenina N. B., Tolstenkov O., Fagerholm H-P., Serbina E. A., VODJANITSKAJA S. N. \& GUSTAFSSON M. K. S. 2006. - The spatial relationship between the musculature and the NADPH-diaphorase activity, 5-HT and the FMRFamide immunoreactivities in redia, cercaria and adult Echinoparyphium aconiatum (Digenea). Tissue Cell 38: 151-157. https://doi.org/10.1016/j.tice.2006.01.003

Tolstenkov O., Terenina N., Kreshchenko N. \& GustafsSON M. 2010. - The pattern of FMRFamide and serotonin immunoreactive elements in the nervous system of Aspidogaster conchicola K. Baer, 1827 (Aspidogastrea). Belgian Journal of Zoology 140: 133-136.

Travassos L. 1927. - Comptes Rendus de la Société de Biologie 97: 844-846. 
Travassos L. 1928. — Fauna helmintologica de Mato Grosso. Trematodeos. (1a. Parte). Memórias do Instituto Oswaldo Cruz 21 (2): 309-341. https://doi.org/10.1590/S0074-02761928000200002 Travassos L. \& KoHN A. 1966. — Lista dos gêneros incluídos na superfamília Brachylaemoidea. Memórias do Instituto Oswaldo Cruz 64: 11-25. https://doi.org/10.1590/S007402761966000100002

Wagner A. 1961. - Papillae on three species of schistosome cercariae. Journal of Parasitology 47: 614-618. https://doi. org/10.2307/3275068
YAMAGUTI S. 1971. - Synopsis of digenetic trematodes of vertebrates. Keigaku Publishing, Tokyo, 1074 p.

YAMAGUTI S. 1975. - Synoptica review of life histories of digenetic trematodes of vertebrates. Keigaku Publishing, Tokyo, 590 p.

Zamparo D., Brooks D. R. \& CAUSEY D. 2003. - Tinamutrema canoae n. gen. et n. sp. (Trematoda: Digenea: Strigeiformes: Brachylaimidae) in Crypturelles cinnamomeus (Aves, Passeriformes, Tinamidae) from the area de conservacion Guanacaste, Costa Rica. Journal of Parasitology 89: 819-822. https://doi. org/10.1645/GE-3100

Submitted on 28 November 2016; accepted on 28 March 2017; published on 29 December 2017. 